\title{
Rules of Court Project
}

\author{
PETER J.M. LOWN, Q.C. *
}

This article describes the Rules Project taken on by the Alberla Lanv Reform Institute to review and make recommendations for a new set of Alberta Rules of Court. The article sets out the project's objectives, along with a background on the project's consultation process and project organization.
Cet article décrit le projet de règles (Rules Project) entrepris par la Alberia Law Reform Institute en vue d'examiner un nowvel ensemble de règles de la cour de l'Alberla el de faine des recommandations pertinentes. $L$ article présente les objectifs du projet ainsi que des antecedenis sur le processus de consulfation et l'organisation du projet.

\section{TABLE OF CONTENTS}

I. INTRODUCTION ............................ 907

II. Project Objectives $\ldots \ldots \ldots \ldots \ldots \ldots \ldots \ldots \ldots \ldots \ldots \ldots \ldots \ldots \ldots \ldots$

III. Consultation Process . . . . . . . . . . . . . . . . . . . . 908

A. CONSUltation WITH THE Legal Community .......... 908

B. Consultation with the Public $\ldots \ldots \ldots \ldots \ldots \ldots \ldots \ldots . \ldots 9$

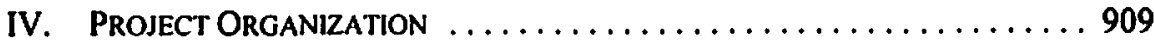

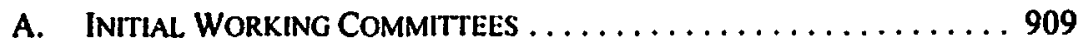

B. Process for DEveloping Policy ReCOMMENDATIONS ....... 910

C. A LARGE AND COMPI.EX PROJECT . ................ 910

\section{INTRODUCTION}

The Rules Project is a three-year project that is undertaking a major review of the Alberta Rules of Court with a view to producing recommendations for a new set of Rules in 2005. The Project is funded by the Alberta Law Reform Institute (ALRI), the Alberta Department of Justice, the Law Society of Alberta and the Alberta Law Foundation, and is managed by ALRI.

Overall leadership and direction of the Rules Project is the responsibility of the Project Steering Committee.

\section{Project Objectives}

While they are subject to an ongoing process of amendment, the Rules have not been comprehensively revised since 1968 . There is a need for rewriting that has arisen over the course of this lengthy period. Further, since 1968, and particularly in the last decade, concerns have been raised as to the timeliness, affordability and understandability of civil court proceedings. Reforms have been adopted to address these issues, some as amendments to the Rules, others by other means.

The Alberta situation is best understood if looked at in the larger context of rules revision and civil justice reform. ALRI research commenced by identifying projects in other 
jurisdictions involving rules or civil justice reform and gathering information about the content of and process employed in those projects. A comprehensive rules revision was completed in British Columbia in $1977^{1}$ and in Ontario in $1985^{2}$ The most recent comprehensive revision was to the Federal Court Rules in $1998 .{ }^{3}$ In addition, in recent years there have been a number of civil justice reform projects, including Ontario's Civil Justice Review: Supplemental and Final Report, ${ }^{4}$ Lord Woolf's report on the English system, Access to Justice and the Canadian Bar Association Report of the Task Force on Systems of Civil Justice.

These reform projects focus on the issues of delay, cost and lack of public understanding of civil justice systems, with the attendant issues of inaccessibility and mistrust of the systems. The reports focus on aspects of procedure that are identified with the issues of cost and delay (notably discovery and expert evidence) and on proposed resolutions to these problems. The proposals include the promotion of early settlement, notably through the incorporation of alternative dispute resolution techniques, employment of different "tracks" for litigation together with case flow management, and judicial case management of complex cases. These same reform areas are reflected in recent Alberta rules changes (for example, changes to discovery rules and streamlined procedure) and practice notes.

The Rules Project Steering Committee has approved Project Objectives that address both the need for rewriting of the Rules and reform issues. The objectives of maximizing the Rules' clarity and useability are goals associated with the "rewriting" of Rules. Such objectives formed a significant part of the impetus for this project. Consultations with the bar support the view that these are essential and central, although not exclusive, goals. The objectives of maximizing the Rules' effectiveness and their advancement of a fair, accessible, timely and cost-effective civil justice system, involve "reforming," or at least "rethinking," the Rules. Consultations with the legal community indicate acceptance that these goals are also appropriately included in the Rules Project.

\section{Consultation Process}

\section{A. Consultation with the Legal Community}

Consultation with the legal community took the form of meetings with local bar associations throughout the province and meetings with law firms and Canadian Bar Association sections in Edmonton and Calgary. An Issues Paper for the Legal Community ${ }^{7}$ was distributed, which described the Rules Project, raised a number of issues and sought input. That input, whether in the form of letters, e-mail or notes from meetings, has been

British Columbia, Supreme Court Rules, B.C. Reg. 310/76.

Ontario, Rules of Procedure, O. Reg. 560/84.

Federal Court Rules, SORM8-106.

(Toronto: Ontario Civil Justice Review, 1996).

Lord Woolf, Access to Justice: Final Report 10 the Lord Chancellor on the Civil Justice System in England and Wales (London: Her Majesty's Stationery Office, 1996).

(Ottawa: The Association, 1996), online:Canadian Bar Association <www.cba.org/CBAcba_Reports/ pdf/systemscivil_tfreport.pdßs.

1 Alberta Rules of Coun Project, Issue Paper for the Legal Community (Edmonton: ALRI, 2001), online: ALRI <www.law.ualberta.ca/alri/pdfs/issuc_pprs/arcissue.pdf $>$. 
categorized and entered into a database. Information from the database is provided to the Working Committees that are described below. Further, a summary Report on the Legal Consultation has been prepared and is available on the ALRI Web site. ${ }^{8}$

\section{B. Consultation with the Public}

Consultation with the public was also undertaken. A Public Consultation Paper and Questionnaire ${ }^{9}$ was prepared and distributed by a number of means. Copies were made available for pickup at courthouse counters and Legal Aid offices. Members of the Legislative Assembly were provided with copies for distribution to interested persons. Advocacy groups and other organizations with interests that relate to the civil justice system received copies, as did lawyers on the Rules Project contact list, who were asked to pass them on to clients. The document was available from ALR in hard copy and was posted as a form on our Web site.

The deadline for the return of questionnaires was 30 June 2002. The responses were collated and a report was prepared by a consulting firm. ${ }^{10}$

\section{Project Organization}

\section{A. INITIAL WORKING COMmitTeES}

The Steering Committee has adopted an organizational structure and approach aimed at ensuring that the Rules Project is not only consultative, but collaborative, directly involving a large number of persons with a diversity of experience and perspectives. The committee structure feflects the "rewriting" and "rethinking" objectives of the Project and ensures that specialized topics will be reviewed by persons with relevant experience. The following working groups have been created:

- General Rules Rewrite Committee

- Early Resolution of Disputes

- Managernent of Litigation

- Discovery and Evidence

- Enforcement of Judgments

- Judicial Review

- Costs

- Appeals

- Criminal Rules

Reform topics have been separated from the overall revision of the Rules of Court. The "Rethink" Committees addressed those areas in which reform issues have been at the

(Edmonton: ALRI, 2002), online: ALRI <wmw.law.ualberta.ca/alri/pdfs/db_report.pdi>. Online: ALRI < www.law.alberna.ca/alri/pdfs/rules/Public_Consultation.pd $\bar{P}$. See also "Alberta Rules of Court Project" Law Now 26:4 (February/March 2002) 20.

Alberta Law Reform Institute, Alberla Rules of Court Public Consultation Report, prepared by Banister Research \& Consulting Inc. (Edmonton: ALRI, 2002) online: ALRI <iww.law.ualberta.ca/alri/ pdfs/rules/Banister2Finalrptl.pdp. 
forefront. Where reforms have already been adopted, these were reviewed and evaluated. Reforms not yet adopted in Alberta have also been considered for inclusion in the Rules.

The General Rewrite Committee has dealt with topics in which, it is thought, the primary focus will be rewriting. The inclusion of a topic in the rewrite category does not preclude review of policy and practice issues related to that topic, it simply indicates an educated guess as to the likely need for a substantial rethinking of policy and practice issues. The General Rewrite Committee also ensures that there will be a comprehensive review of the Rules, as it will have the responsibility of dealing with all Rules not assigned to a specialized committee.

\section{B. Process for Developing Policy Recommendations}

The major task for Working Committees is the development of policy recommendations regarding each of the topics included in their mandates. These policy recommendations have been written up by ALRI counsel in the form of consultation memoranda and distributed to the bar and bench for feedback. The committees subsequently reviewed the feedback and approved drafting instructions and draft rules.

In developing policy recommendations each Working Committee reviewed comments received through the Legal and Public Consultations described above.

The Rules Project is reaching a crucial stage when we are coming into the last year and one half of the project, and every element of the project is now in play. We have some working groups that have completed their research and policy, put out their consultation memoranda and received consultation. On the basis of the consultation, they have reviewed their proposals and have now produced final proposals and drafting instructions for the preparation of the new rules in that subject areas. Others are completing the preparation of drafting instructions, while yet others are circulating the consultation memoranda for consultation.

In addition, we are beginning to identify some overarching areas, with which the Steering Committee must address. The Steering Committee must also iron out any wrinkles that may occur if there are inconsistencies or difficulties between the recommendations of various working groups.

One of the goals of the project, and the process adopted, was to be as open and consultative as possible. This has been done proactively by engaging different groups to provide feedback and more passively by ensuring the widest possible circulation of materials. The ALRI Web site contains all the materials as well as notices of upcoming publications.

\section{A large and Complex Project}

To say that the project is large does not really allow the reader or participant to comprehend the different measures by which the project could be described as large. Under the supervision of the Board and the Steering Committee, the Project has been broken down into Working Committees dealing with discrete subject areas. There are 11 working groups. 
So far these working groups have produced 16 formal consultation memoranda and eight public issues papers. They have met 114 times, usually for durations of two to three hours. The General Rewrite Committee, which has ongoing responsibility for any topic not specifically assigned to another working group has met 27 times over the two years since it was created. It has produced by itself, six consultation memoranda.

A program of this size, duration and complexity, demands a large degree of coordination. Our project management template now runs to 64 pages in length and documents 754 tasks (and counting) distributed among the various working groups and participants. Tracking the coordination and completion and documentation of each of these tasks is a challenge. Similarly, the periodic "all staff" meetings to disclose and discuss progress have been essential. All of this activity has therefore forced us to focus on and review how efficiently we carry out certain activities, and we have paid close attention to the following tasks:

- the need to coordinate the research and writing activities of our counsel;

- the logistics of meeting organization and distribution of materials;

- the recording of discussion and policy decisions of the working committees for inclusion in subsequent consultation memoranda; coordination of topics among the various working groups;

- formatting and production process for hard copy and electronic distribution of consultation memoranda;

- progress reporting to all stakeholders and interested parties;

- the recording and integration of all feedback on consultation memoranda; and

- the budget control over the integrated financing of the three-plus year project.

The final phase of the project is the preparation of a comprehensive draft for presentation to the Rules of Court Committee. If the draft is approved, it will be forwarded for passage, and the educational process can begin to prepare the profession and court personnel for implementation. 